Article

\title{
Improving Hydro-Climatic Projections with Bias-Correction in Sahelian Niger Basin, West Africa
}

\author{
Ganiyu Titilope Oyerinde 1,* Fabien C. C. Hountondji 1,2, Agnide E. Lawin ${ }^{3}$, Ayo J. Odofin ${ }^{4}$, \\ Abel Afouda ${ }^{1}$ and Bernd Diekkrüger ${ }^{5}$ \\ 1 Graduate Research Program (GRP) Climate Change and Water Resources, \\ West African Science Service Center on Climate Change and Adapted Land Use (WASCAL), \\ University of Abomey-Calavi, Abomey-Calavi BP 2008, Benin; fabienho@yahoo.com (F.C.C.H.); \\ aafouda@yahoo.fr (A.A.) \\ 2 Ecole Nationale Supérieure des Sciences et Techniques Agronomiques de Djougou, University of Parakou, \\ Parakou BP 123, Benin \\ 3 Laboratory of Applied Hydrology, National Water Institute, University of Abomey-Calavi, \\ Abomey-Calavi BP526, Benin; ewaari@yahoo.fr \\ 4 Department of Soil Science and Land Management, Federal University of Technology, P.M.B 65, \\ Gidan-Kwanu, 920212 Minna, Nigeria; odofinayo@yahoo.co.uk \\ 5 Department of Geography, University of Bonn, Meckenheimer Allee 166, 53115 Bonn, Germany; \\ b.diekkrueger@uni-bonn.de \\ * Correspondence: ganiyuoyerinde@yahoo.com; Tel.: +234-703-683-5998
}

Academic Editors: Nir Y. Krakauer, Tarendra Lakhankar, Ajay K. Jha and Vishnu Pandey Received: 6 December 2016; Accepted: 10 February 2017; Published: 15 February 2017

\begin{abstract}
Climate simulations in West Africa have been attributed with large uncertainties. Global climate projections are not consistent with changes in observations at the regional or local level of the Niger basin, making management of hydrological projects in the basin uncertain. This study evaluates the potential of using the quantile mapping bias correction to improve the Coupled Model Intercomparison Project (CMIP5) outputs for use in hydrological impact studies. Rainfall and temperature projections from 8 CMIP5 Global Climate Models (GCM) were bias corrected using the quantile mapping approach. Impacts of climate change was evaluated with bias corrected rainfall, temperature and potential evapotranspiration (PET). The IHACRES hydrological model was adapted to the Niger basin and used to simulate impacts of climate change on discharge under present and future conditions. Bias correction with quantile mapping significantly improved the accuracy of rainfall and temperature simulations compared to observations. The mean of six efficiency coefficients used for monthly rainfall comparisons of 8 GCMs to the observed ranged from 0.69 to 0.91 and 0.84 to 0.96 before and after bias correction, respectively. The range of the standard deviations of the efficiency coefficients among the 8 GCMs rainfall data were significantly reduced from $0.05-0.14$ (before bias correction) to 0.01-0.03 (after bias correction). Increasing annual rainfall, temperature, PET and river discharge were projected for most of the GCMs used in this study under the RCP4.5 and RCP8.5 scenarios. These results will help improving projections and contribute to the development of sustainable climate change adaptation strategies.
\end{abstract}

Keywords: climate change; evapotranspiration; IHACRES model; rainfall; runoff; quantile mapping

\section{Introduction}

Climate change impacts are expected to exacerbate poverty in most developing countries and create new poverty pockets in countries with increasing inequality in both developed and developing countries [1]. Water resources are fundamental for several sectors such as hydropower, crop production and fisheries in Africa [2]. Runoff evolutions in the West African region have been strongly affected by 
rainfall variations. Climate change has driven decreased discharge and increased drought in the Sahel, a transition zone between the Sahara desert and Sudan zones of west Africa, since 1970, with partially wetter conditions experienced since 1990 [1,3,4]. Recently, reduction in rainfall of 10 to $30 \%$ on the Niger river, which is the major source of water for some Sahelian countries (Mali, Niger and Burkina Faso), has led to a deficit of $20 \%$ to $60 \%$ in river discharge [5]. Severe decrease of river flows in the basin was also observed mainly due to the 1970s' droughts [6].

Future climate simulations in the region have been a challenge for researchers using existing climate models [7]. Rapid forest disappearance or deterioration, especially due to population pressures and non-sustainable resource utilization [8], poses great challenge to land surface schemes of global climate model (GCM) and regional climate model (RCM). Consequently GCM projections in West Africa are accrued with different biases relative to regional observations and no coherent rainfall trend emerges from GCM products [9]. Vetter et al. [10] disclosed that scenarios from climate models are the largest uncertainty source, providing large discrepancies in precipitation, and therefore clear hydrological projections are difficult. Changes in hydrological regimes could become even more important in the future. In combination with increasing demographic pressure and low adaptive capacity, these changes will have significant impacts on people and sectors that depend on water resources in West Africa [2]. Thus, there is a need to comprehend regional impacts of climate change on water resources.

Numerous studies [7,11-19] have assessed future trends of climate change in the region. Most of these studies either utilized the CMIP3 archive or worked on the large scale without giving finer basin scale information that are important for hydrological change evaluations. The studies showed that projections by GCMs are not consistent concerning the patterns of hydroclimatic changes and this makes management of hydrological projects difficult [20,21]. Recently, Biasutti [22] reported a more consistent trend in CMIP5 climate projections relative to CMIP3. Expectations of increasing rainfalls across the Sahel are also evident in CMIP5 climate projections [18,22]. However, with the recent attribution of CMIP5 datasets with regional biases and uncertainties [10,18,22,23], there is a need for improving the datasets in the assessments of impacts of climate change on water resources in the largest river basin in West Africa. Several ways have been developed to correct biases in climate modeling using statistical, parametric, non-parametric and spline transformations. A comparative study among the above highlighted bias correction approaches revealed that parametric quantile-quantile transformation (quantile mapping) effectively corrected climate model biases and reduced systematic errors [24].

This study thereby enhanced datasets of 8 CMIP5 GCMs by using quantile mapping bias correction and the improved datasets were used to evaluate future hydro-climatic conditions in the Sahelian Niger basin. The objectives of the study are to improve data projections, to assess projected trends of rainfall, temperature and potential evapotranspiration (PET) under RCP4.5 and RCP8.5 scenarios and therefore climate change impacts on river discharge in the Niger basin using an improved IHACRES hydrological model.

\section{Materials and Methods}

\subsection{Study Area}

The Niger River Basin covers an area of about 2.27 million $\mathrm{km}^{2}$. The basin is drained by the third longest river in Africa [25] (Figure 1). The Niger basin covers different climatic zone with a very large percentage of it being in the Sahel. Upstream area of the evaluated hydrological station used in this study (Figure 1) covers about 1.61 million $\mathrm{km}^{2}$ (about $70 \%$ of the basin). The hydrological station is located at the fringe of the Sahel in the Niger basin. Rainfall ranges from 250 to $750 \mathrm{~mm}$ /year in this region with a length of the rainy season varying from 3 to 7 months [20]. Two flooding regimes are prominent on the catchment. During May to October, flash floods from northern Benin and some parts of Niamey produce the white flood with a maximum flow of about $3500 \mathrm{~m}^{3} / \mathrm{s}$ (based on observations 
from 1980 to 2010). The black flood comes from the river source region caused by high rainfall in November with a maximum flow of about $2000 \mathrm{~m}^{3} / \mathrm{s}$ (based on observations from 1980 to 2010). Since 1990, more frequent extreme events in the two flooding regimes have led to increased floods in the Niger basin [26].

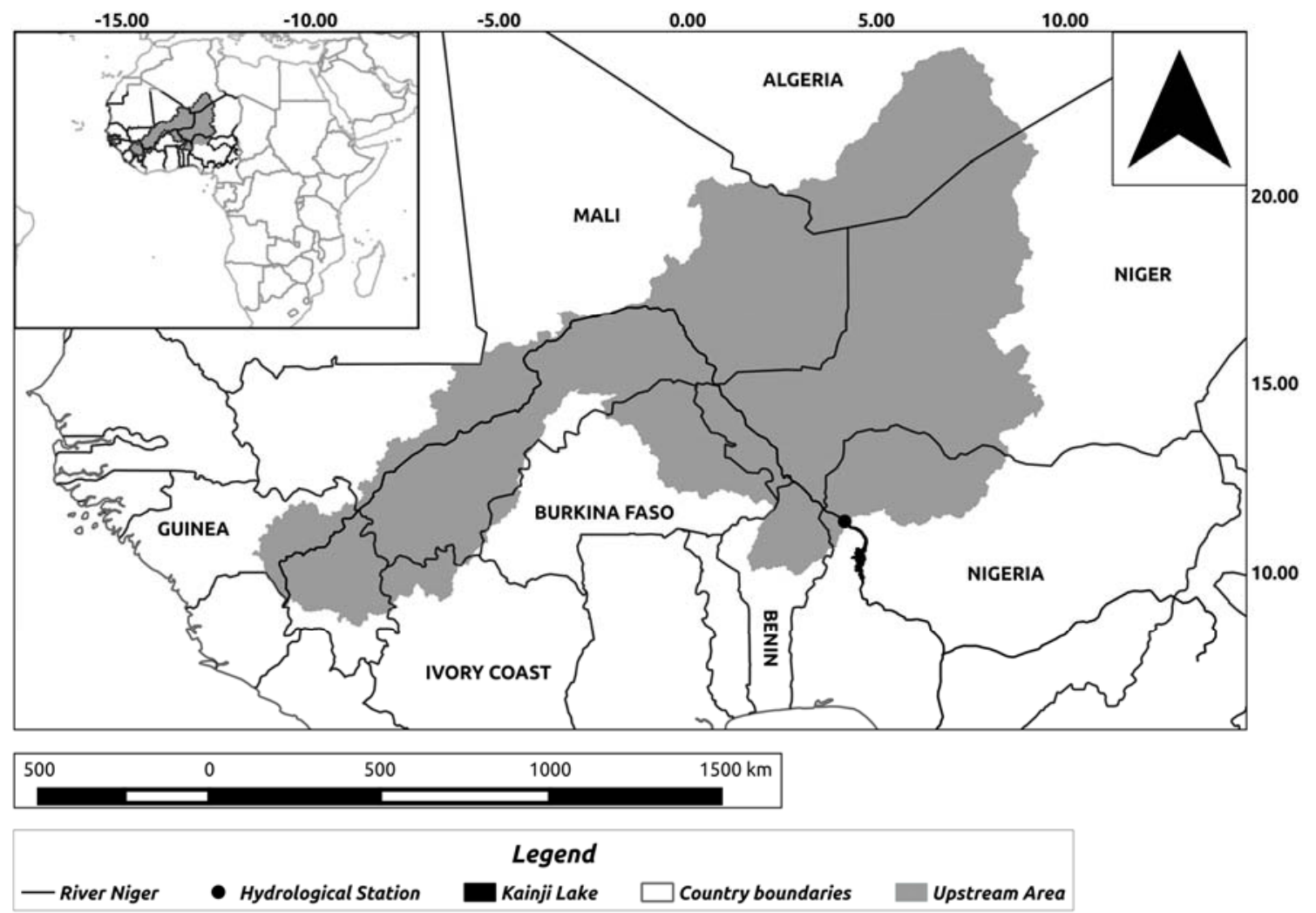

Figure 1. Upstream Niger basin area of Jidere Bode hydrological station.

\subsection{Hydrological Model}

The hydrological model used in the present study, is a daily, lumped parameter, conceptual rainfall-runoff model which was implemented on the $\mathrm{R}$ based Hydromad $[27,28]$. It consists of three modules; the first was a non-linear IHACRES catchment wetness index (CWI) loss module [29]. CWI is chosen because it is the best configuration of IHACRES model in semi-arid regions [29,30]. The loss module which has five parameters converts rainfall to effective rainfall which is defined as the amount of rainfall that is not lost in the catchment [29,31,32]. The second was an ARMAX module with four parameters which was used for routing effective rainfall to stream flow [31,33]. The IHACRES model is a highly flexible model that readily allows coupling of new modules. In this study, a third module which fits the quantiles of simulated and observed discharge was introduced. The loss module involves calculation of an index of catchment storage $s_{k}$, at each time step k (daily in this paper) based upon an exponentially decreasing weighting of precipitation and potential evapotranspiration (PET) (or temperature) conditions [29,34]. It is a metric-type model, where rainfall effectiveness is proportional to a simple antecedent moisture index, and the output is scaled to enforce mass balance [35]. During a model calibration, four of the five soil moisture parameters (storage/soil moisture index $\left(s_{k}\right)$ scale factor $(c)$, modulating factor $(f)$ and moisture threshold $(l)$ ) were determined directly from the raw rainfall, streamflow and temperature/PET data with the aid of an optimization algorithm 'fitByOptim' [27] once the effective rainfall series $u_{k}$ is constructed. The remaining parameters are power on soil moisture $(p)$ and the ARMAX routing parameters (auto-regressive terms a and moving average terms $\mathrm{b}$ ). The effective rainfall $u_{k}$ was computed from 
incidence precipitation $r_{k}$, PET $E_{k}$, drying rate $\mathrm{tw}_{\mathrm{k}}$ and storage/soil moisture index $s_{k}$ as described by Ye et al. [29], Jakeman et al. [34] and Andrews [35].

$$
\begin{gathered}
u_{k}=c \times\left(s_{k}-l\right)^{p} \times r_{k} \\
s_{k}=\left(1-1 / \mathrm{tw}_{\mathrm{k}}\right) \times s_{k-1}+r_{k} \\
\mathrm{tw}_{\mathrm{k}}=t w \times \exp \left(-0.062 \times f \times E_{k}\right)
\end{gathered}
$$

The effective rainfall was routed to streamflow $\left(x_{k}\right)$ using the following ARMAX transfer function [31].

$$
x_{k}=a_{1} x_{k-1}+\ldots+a_{n} x_{k-n}+b_{0} u_{k-d}+\ldots+b_{m} u_{k-m-d}
$$

The order is denoted $(n, m)$, with delay $d$.

fitByOptim automatically samples the parameter space of the loss module comprehensively with the Bell Labs PORT library function [27], each sample generating a $x_{k}$ series. NSE model performance statistics between observed and simulated discharge are calculated for each sample. From these the optimum $x_{k}$ series is selected as the preferred model.

The third quantile module is a parametric transformation of the quantile-quantile relation of observed $Q_{o}$ and modeled $\left(x_{k}\right)$ discharge with power function shown below (where $\mathrm{b}$ and $\mathrm{c}$ are parameters subject to calibration). The transformation aims at adjusting the distribution of $x_{k}$ to match the quantiles of the observed discharge $\left(Q_{o}\right)$.

$$
Q_{o}=b x_{k}^{c}
$$

The model needs daily rainfall, PET and river discharge as inputs. The Global Precipitation Climatology Project (GPCP) provided daily rainfall [36], daily temperature was obtained from the Modern Era Retrospective-Analysis for Research and Applications (MERRA) [37] and observed daily river discharge obtained from the Niger Basin Authority were used in the study. MERRA and GPCP were selected due to inadequate meteorological observation stations in the region [38]. The two datasets are available and commonly deployed in regional hydrological studies $[39,40]$. GPCP daily rainfall is known to have very low total bias to observed rainfall in the Sahel [40]. GPCP daily rainfall is available from 1997, MERRA temperature from 1979 and discharge data on the station highlighted in Figure 1 is available from 1980. Upstream area of the hydrological station (Figure 1) was delineated using a DEM provided by Hydrosheds [41] using the Hortonian drainage networks analysis [42]. Rainfall and temperature distribution in West Africa have been attributed to the back and forth movement of the Inter Tropical Convergence Zone (ITCZ) [43]. The movement of the ITCZ follows the position of maximum surface heating associated with meridional displacement of the overhead position of the sun. Due to the ITCZ, lower latitudes witness greater rainfall and cooler temperature while higher latitudes go through less rainfall and warmer temperatures. In order to account for the latitudinal ITCZ gradients, rainfall and temperature were computed using weighted average with latitudes. The latitudes were ranked and the ranks were used as weights for computing the averages. For computation of temperature, higher latitudes have higher ranks than lower latitudes while the reverse was applied for rainfall.

Catchment observed PET was computed from the extracted MERRA 2 meter daily air temperature using the Hamon model [44]. Future projections of rainfall and temperature data from 8 GCMs (Table 1) with two emission scenarios (RCP4.5 and RCP8.5) were downloaded from the Coordinated Regional Downscaling Experiment (CORDEX) for Africa. CORDEX is a program sponsored by World Climate Research Program (WCRP) to develop an improved framework for generating regional-scale climate projections for impact assessment and adaptation studies worldwide within the IPCC AR5 timeline and beyond [45]. Climate projection framework within CORDEX is based on the set of new global model simulations planned in support of the IPCC Fifth Assessment Report, referred to as CMIP5 [46]. 
This set of simulations includes a large number of experiments, ranging from new greenhouse-gas scenario simulations for the 21st century, decadal prediction experiments including the carbon cycle and experiments aimed at investigating individual feedback mechanisms [46]. These simulations are based on the reference concentration pathways (RCPs), i.e., prescribed greenhouse-gas concentration pathways throughout the 21st century, corresponding to different radiative forcing stabilization levels by the year 2100. The RCPs are formulated based on range of projections of future population growth, technological development, and societal responses. Within CMIP5, the highest-priority global model simulations have been selected to be the RCP4.5 and RCP8.5, roughly corresponding to the Intergovernmental Panel on Climate Change (IPCC) Special Report on Emissions Scenarios (SRES) B1 and A1B, respectively. The same scenarios are therefore also the highest priority CORDEX simulations [45] that was utilized in this study. Radiative forcing in RCP4.5 and RCP8.5 increases throughout the twenty-first century before reaching a level of about $4.5 \mathrm{~W} / \mathrm{m}^{2}$ and $8.5 \mathrm{~W} / \mathrm{m}^{2}$ respectively, at the end of the century. The 8 GCMs were dynamically downscaled to about $50 \mathrm{~km}$ resolution using the Sveriges Meteorologiska och Hydrologiska Institute-Rossby Centre Regional Atmospheric Model (SMHI-RCA) RCM within CORDEX. Future PET was computed from bias corrected temperature as described before. Similar to the study of Su et al. [47], future seasonal (meteorological) and monthly rainfall patterns of two future time periods ("near future" (2010-2035) and "far future" (2036-2099)) were compared to the historical period (1961-2005). Significance of changes in projected hydro-climatic variables was assessed with the student's $t$-test and the change point approach of Killick [48].

Table 1. List of CMIP5 Global Climate Models (GCMs) considered in the study.

\begin{tabular}{|c|c|c|c|}
\hline Modeling Center (or Group) & Country & Institute ID & Model Name \\
\hline Canadian Centre for Climate Modeling and Analysis & Canada & CCCMA & CanESM2 \\
\hline $\begin{array}{l}\text { Centre National de Recherches Météorologiques/Centre } \\
\text { Européen de Recherche et Formation Avancée en } \\
\text { Calcul Scientifique }\end{array}$ & France & CNRM-CERFACS & CNRM-CM5 \\
\hline NOAA Geophysical Fluid Dynamics Laboratory & USA & NOAA GFDL & GFDL-ESM2M \\
\hline $\begin{array}{l}\text { Met Office Hadley Centre (additional HadGEM2-ES } \\
\text { realizations contributed by Instituto Nacional de } \\
\text { Pesquisas Espaciais) }\end{array}$ & UK & $\mathrm{MOHC}$ & HadGEM2-ES \\
\hline $\begin{array}{l}\text { Atmosphere and Ocean Research Institute (The University of } \\
\text { Tokyo), National Institute for Environmental Studies, } \\
\text { and Japan Agency for Marine-Earth Science and Technology }\end{array}$ & Japan & MIROC & MIROC5 \\
\hline $\begin{array}{l}\text { Max-Planck-Institut für Meteorologie (Max Planck Institute } \\
\text { for Meteorology) }\end{array}$ & Germany & MPI-M & MPI-ESM-LR \\
\hline Norwegian Climate Centre & Norway & NCC & NorESM1-M \\
\hline EC-EARTH consortium & Ireland & EC-EARTH & EC-EARTH \\
\hline
\end{tabular}

\subsection{Bias Adjustment of GCM/RCMs and Their Evaluation}

Bias-Correction removes errors from data from climate models in comparison with historical observations [49]. It relies on computation of differences between RCM/GCM and satellite-based estimates in regions with limited rain gauges [49]. In this study, the RCM/GCM datasets were bias corrected with respect to daily MERRA and GPCP datasets from 1997 to 2010. The quantile mapping bias correction $[19,24,50]$ was applied for improving the CMIP5 rainfall and temperature projections. Quantile mapping adjusts all moments of the probability distribution function (PDF) of input variable by deriving both cumulative distribution functions (CDFs) also known as quantile function from the PDFs of the observed and RCM in the historical or reference period here taken as 1997-2010. Similar to the study of Sarr et al. [51], Ravazzani et al. [50] and Oyerinde et al. [19], quantile functions were computed independently for daily time series of each month from both observations and RCM (rainfall and temperature). All parametric transformations for rainfall were fitted to the fraction of 
the CDF corresponding to observed wet days $\left(P_{o}>0\right)$ by minimizing the residual sum of squares [24]. For temperature, no wet day correction was applied and the CDF was fitted through the minimization of the residual sum of squares. The derived monthly quantile functions for rainfall and temperature from the reference period was then used to correct monthly rainfall and temperature time series of the RCM data from 1961-2100.

$$
P_{o}=b P_{m}^{c}
$$

where $P_{o}$ refers to observed and $P_{m}$ to RCM empirical cumulative distribution functions (CDF) and $\mathrm{b}$ and $\mathrm{c}$ are free parameters.

The mapping was conducted separately for each month. The original daily RCM/GCM and bias corrected rainfall and temperature data were compared with the observed using six efficiency coefficients namely: Nash-Sutcliffe Efficiency ( $\infty \leq N S E \leq 1)$ [52], Index of Agreement $(0 \leq d \leq 1)$ [53], Modified Index of Agreement $(0 \leq m d \leq 1)$ [53], Pearson Correlation Coefficient $(-1 \leq r \leq 1)$ [53], Coefficient of Determination $\left(0 \leq R^{2} \leq 1\right)$ [53] and Kling-Gupta Efficiency $(0 \leq K G E \leq 1)$ [49]. The levels of significance of the improvements were measured with $t$-test.

\subsection{Hydrological Model Calibration and Validation}

Hydrological model evaluation was conducted for fourteen years (1997-2010) using GPCP daily rainfall, PET and observed river discharge. Calibration of the hydrological model was done for the period of 1997-2003, while validation for the period of 2004-2010. The choice of the calibration time span was based on data availability. Shin et al. [54] reported five years as the minimum length of daily records required to attain stable IHACRES parameters. The model was automatically calibrated for the stipulated periods with the optimization of the Nash efficiency. The calibrated hydrological model was then used to predict daily runoff by using bias corrected rainfall, and PET (computed from bias corrected temperature projections) datasets from $8 \mathrm{GCMs}$ under two emission scenarios from the CORDEX regional downscaling experiments.

During hydrological model calibration and validation (Figure 2), high correlation efficiency coefficients were observed between simulated and observed discharge. Efficiency coefficients of $0.92(N S E), 0.98(d), 0.89(m d), 0.96(r), 0.92\left(R^{2}\right)$ and $0.96(K G E)$ were recorded for model calibration, while $0.80(N S E), 0.95(d), 0.82(m d), 0.91(r), 0.83\left(R^{2}\right)$ and $0.88(K G E)$ were recorded for model validation. This implies that the model was able to adequately simulate river discharge in the Niger basin and could be used in projecting discharge trends.
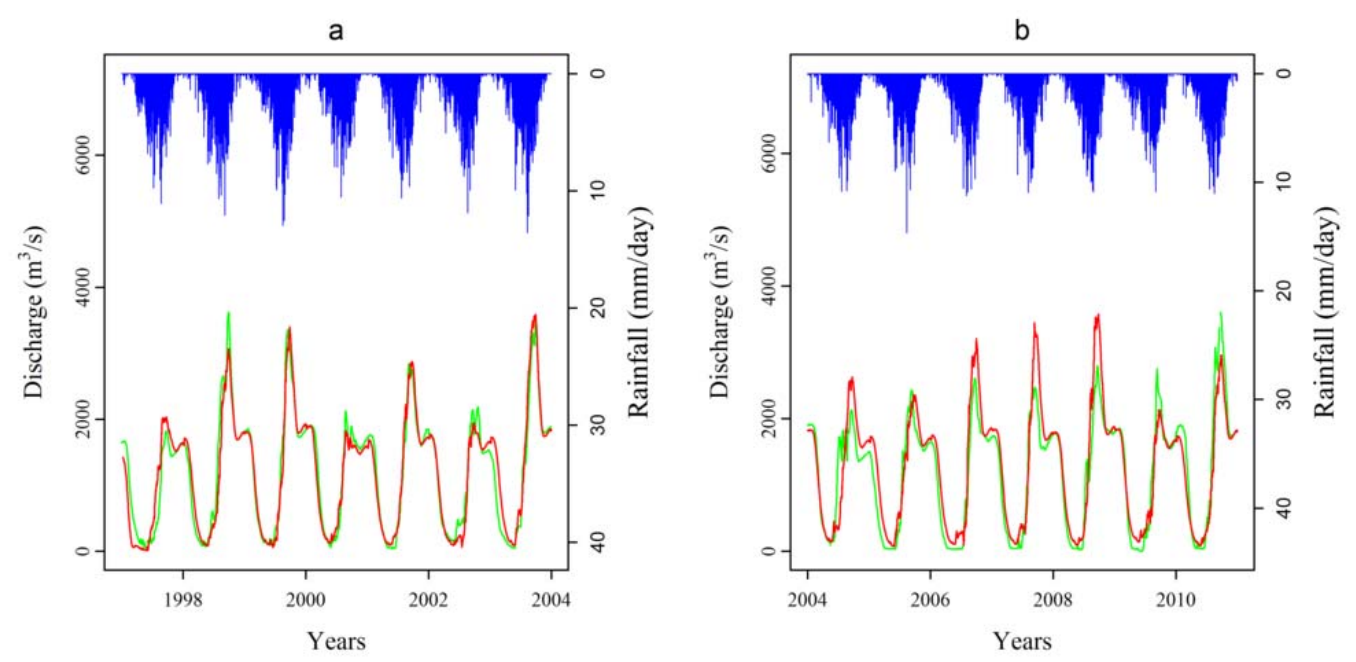

Figure 2. Calibration (a) and validation (b) of the hydrological model with observed data in the Niger Basin; inverted blue bars represent GPCP rainfall while green and red lines are observed and simulated runoff, respectively. 


\section{Results}

\subsection{CMIP5 Model Improvements with Bias Correction}

Comparison of the models (8 GCMs) and bias corrected simulations to the GPCP and MERRA observed rainfall and temperature are presented in Figure 3. The outputs of all GCMs underestimated daily climatological (daily mean from 1997-2010) and monthly mean temperatures. However the outputs of all GCMs underestimated and overestimated daily mean and monthly mean rainfalls. These outputs were adequately corrected by quantile mapping bias correction (Figure 2). Mean and standard deviation of efficiency coefficients to observed among the 8 GCMs (Tables 2 and 3) were significantly $(p<0.05)$ improved by bias correction during seasonal (winter (December-February), spring (March-May), summer (June-August) and autumn (September-November)), monthly and daily climatological comparisons (Table 2). Individual GCM monthly Nash-Sutcliffe Efficiency of rainfall (Table 3) before bias correction revealed that CNRM-CM5 (NSE $=0.81$ ) had the highest NSE value compared to observed data. Other efficiency coefficients $\left(d, m d, r, R^{2}\right)$ followed similar pattern except KGE where highest value of 0.87 was recorded by MPI-ESM-LR and HadGEM2-ES. NorESM1-M had the lowest NSE, $d, r$ and $R^{2}$ before bias correction while CanESM2 has the lowest $m d$ and KGE. Before bias correction, temperature indicated that MIROC5 has the highest NSE values, MIROC5 and CanESM2 also recorded the highest $d$ and $m d$, the best $r$ and $R^{2}$ values was found by MPI-ESM-LR and CanESM2 while highest KGE was recorded by MPI-ESM-LR. EC-EARTH had low NSE, $d, m d, r$ and KGE values. Bias correction improved the efficiency coefficients of all the 8 GCMs with rainfall NSE being about $0.80, d$ and $r$ are more than 0.90 and $m d, R^{2}$ and KGE are greater than 0.80 (Table 3). Similar improvements were found in temperature efficiency coefficients where the efficiency coefficients were above 0.90 for all the GCMs (Table 3).

Table 2. Means and standard deviations of efficiency coefficients (8 GCMs) compared to observations before and after bias correction at monthly, seasonal (meteorological) and climatological time frames. Nash-Sutcliffe Efficiency $(\infty \leq N S E \leq 1)$ [52], Index of Agreement $(0 \leq d \leq 1)$ [53], Modified Index of Agreement $(0 \leq m d \leq 1)$ [53], Pearson Correlation Coefficient $(-1 \leq r \leq 1)$ [53], Coefficient of Determination $\left(0 \leq R^{2} \leq 1\right)$ [53] and Kling-Gupta Efficiency $(0 \leq K G E \leq 1)$ [49].

\begin{tabular}{|c|c|c|c|c|c|c|c|c|}
\hline \multirow{3}{*}{$\begin{array}{l}\text { Efficiency } \\
\text { Coefficients }\end{array}$} & \multicolumn{4}{|c|}{ Rainfall } & \multicolumn{4}{|c|}{ Temperature } \\
\hline & \multicolumn{2}{|c|}{ Before } & \multicolumn{2}{|c|}{ Bias Corrected } & \multicolumn{2}{|c|}{ Before } & \multicolumn{2}{|c|}{ Bias Corrected } \\
\hline & Mean & Std & Mean & Std & Mean & Std & Mean & Std \\
\hline \multicolumn{9}{|c|}{ Monthly } \\
\hline NSE & 0.69 & 0.13 & 0.84 & 0.03 & 0.67 & 0.16 & 0.96 & 0.01 \\
\hline$d$ & 0.91 & 0.05 & 0.96 & 0.01 & 0.92 & 0.04 & 0.99 & $<0.01$ \\
\hline$m d$ & 0.78 & 0.05 & 0.85 & 0.01 & 0.71 & 0.08 & 0.91 & 0.01 \\
\hline$r$ & 0.86 & 0.06 & 0.93 & 0.01 & 0.97 & 0.00 & 0.98 & $<0.01$ \\
\hline$R^{2}$ & 0.74 & 0.10 & 0.86 & 0.02 & 0.95 & 0.01 & 0.96 & 0.01 \\
\hline$K G E$ & 0.75 & 0.14 & 0.90 & 0.02 & 0.87 & 0.03 & 0.98 & $<0.01$ \\
\hline \multicolumn{9}{|c|}{ Seasonal (meteorological season) } \\
\hline NSE & 0.76 & 0.14 & 0.92 & 0.02 & 0.64 & 0.19 & 0.98 & 0.01 \\
\hline$d$ & 0.93 & 0.05 & 0.98 & 0.01 & 0.92 & 0.04 & 0.99 & $<0.01$ \\
\hline md & 0.78 & 0.07 & 0.88 & 0.01 & 0.67 & 0.08 & 0.92 & 0.01 \\
\hline$r$ & 0.91 & 0.05 & 0.96 & 0.01 & 0.98 & 0.01 & 0.99 & $<0.01$ \\
\hline$R^{2}$ & 0.83 & 0.09 & 0.92 & 0.02 & 0.97 & 0.00 & 0.98 & 0.01 \\
\hline$K G E$ & 0.76 & 0.14 & 0.94 & 0.02 & 0.87 & 0.03 & 0.99 & 0.01 \\
\hline \multicolumn{9}{|c|}{ Climatological (daily mean from 1997-2010) } \\
\hline NSE & 0.74 & 0.15 & 0.90 & 0.02 & 0.71 & 0.15 & 1.00 & 0.01 \\
\hline$d$ & 0.92 & 0.05 & 0.98 & 0.00 & 0.93 & 0.04 & 1.00 & $<0.01$ \\
\hline$m d$ & 0.80 & 0.06 & 0.89 & 0.01 & 0.71 & 0.08 & 0.97 & $<0.01$ \\
\hline$r$ & 0.89 & 0.06 & 0.96 & 0.01 & 0.99 & 0.00 & 1.00 & $<0.01$ \\
\hline$R^{2}$ & 0.79 & 0.11 & 0.91 & 0.01 & 0.98 & 0.01 & 1.00 & 0.01 \\
\hline$K G E$ & 0.76 & 0.15 & 0.94 & 0.01 & 0.87 & 0.03 & 1.00 & $<0.01$ \\
\hline
\end{tabular}


Table 3. Monthly efficiency coefficients of 8 GCMs compared to observations before and after bias correction. Nash-Sutcliffe Efficiency ( $\infty \leq$ NSE $\leq 1$ ) [52], Index of Agreement $(0 \leq d \leq 1)$ [53], Modified Index of Agreement $(0 \leq m d \leq 1)$ [53], Pearson Correlation Coefficient $(-1 \leq r \leq 1)$ [53], Coefficient of Determination $\left(0 \leq R^{2} \leq 1\right)$ [53] and Kling-Gupta Efficiency $(0 \leq K G E \leq 1)$ [49].

\begin{tabular}{|c|c|c|c|c|c|c|c|c|c|c|c|c|}
\hline \multirow{2}{*}{ GCMs } & \multicolumn{6}{|c|}{ Before } & \multicolumn{6}{|c|}{ Bias Corrected } \\
\hline & $N S E$ & $d$ & $m d$ & $r$ & $R^{2}$ & $K G E$ & NSE & $d$ & $m d$ & $r$ & $R^{2}$ & $K G E$ \\
\hline & \multicolumn{12}{|c|}{ Rainfall } \\
\hline GFDL-ESM2M & 0.74 & 0.93 & 0.8 & 0.87 & 0.76 & 0.85 & 0.79 & 0.95 & 0.83 & 0.91 & 0.82 & 0.87 \\
\hline NorESM1-M & 0.46 & 0.84 & 0.71 & 0.73 & 0.53 & 0.69 & 0.82 & 0.96 & 0.85 & 0.92 & 0.84 & 0.9 \\
\hline MPI-ESM-LR & 0.8 & 0.95 & 0.82 & 0.9 & 0.81 & 0.87 & 0.87 & 0.97 & 0.86 & 0.94 & 0.88 & 0.92 \\
\hline HadGEM2-ES & 0.78 & 0.94 & 0.81 & 0.89 & 0.79 & 0.87 & 0.85 & 0.96 & 0.84 & 0.93 & 0.86 & 0.91 \\
\hline MIROC5 & 0.76 & 0.93 & 0.8 & 0.87 & 0.76 & 0.83 & 0.85 & 0.96 & 0.85 & 0.93 & 0.86 & 0.91 \\
\hline EC-EARTH & 0.64 & 0.89 & 0.75 & 0.82 & 0.67 & 0.72 & 0.85 & 0.96 & 0.86 & 0.93 & 0.87 & 0.91 \\
\hline CNRM-CM5 & 0.81 & 0.95 & 0.82 & 0.93 & 0.86 & 0.76 & 0.84 & 0.96 & 0.85 & 0.93 & 0.86 & 0.9 \\
\hline \multirow[t]{2}{*}{ CanESM2 } & 0.52 & 0.84 & 0.69 & 0.88 & 0.77 & 0.44 & 0.88 & 0.97 & 0.87 & 0.94 & 0.89 & 0.91 \\
\hline & \multicolumn{12}{|c|}{ Temperature } \\
\hline GFDL-ESM2M & 0.54 & 0.89 & 0.64 & 0.97 & 0.94 & 0.87 & 0.95 & 0.99 & 0.9 & 0.97 & 0.95 & 0.97 \\
\hline NorESM1-M & 0.73 & 0.93 & 0.72 & 0.97 & 0.94 & 0.88 & 0.96 & 0.99 & 0.92 & 0.98 & 0.96 & 0.98 \\
\hline MPI-ESM-LR & 0.75 & 0.94 & 0.73 & 0.98 & 0.96 & 0.9 & 0.97 & 0.99 & 0.92 & 0.98 & 0.97 & 0.98 \\
\hline HadGEM2-ES & 0.75 & 0.94 & 0.73 & 0.97 & 0.94 & 0.89 & 0.96 & 0.99 & 0.91 & 0.98 & 0.96 & 0.98 \\
\hline MIROC5 & 0.86 & 0.96 & 0.8 & 0.97 & 0.94 & 0.83 & 0.96 & 0.99 & 0.92 & 0.98 & 0.96 & 0.98 \\
\hline EC-EARTH & 0.45 & 0.87 & 0.6 & 0.97 & 0.95 & 0.82 & 0.96 & 0.99 & 0.91 & 0.98 & 0.96 & 0.98 \\
\hline CNRM-CM5 & 0.48 & 0.88 & 0.62 & 0.97 & 0.94 & 0.86 & 0.96 & 0.99 & 0.92 & 0.98 & 0.96 & 0.98 \\
\hline CanESM2 & 0.81 & 0.96 & 0.8 & 0.98 & 0.96 & 0.89 & 0.96 & 0.99 & 0.91 & 0.98 & 0.96 & 0.98 \\
\hline
\end{tabular}




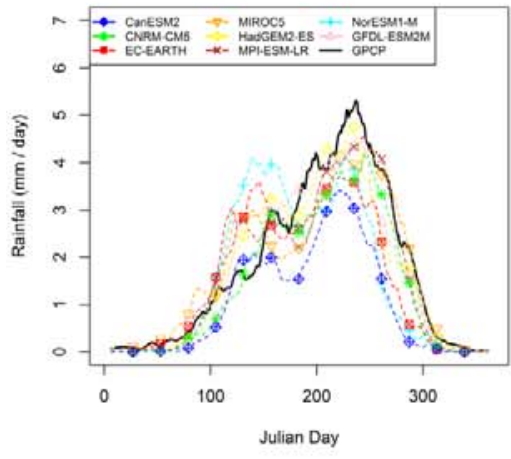

e

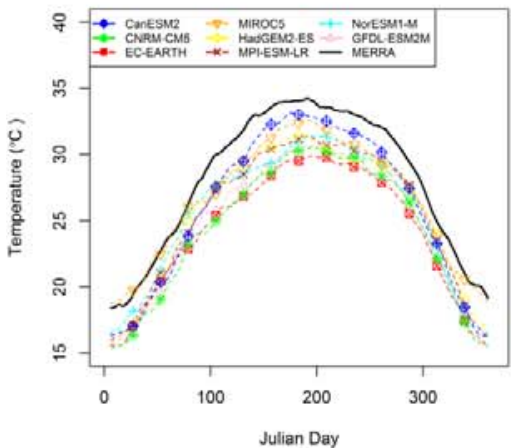

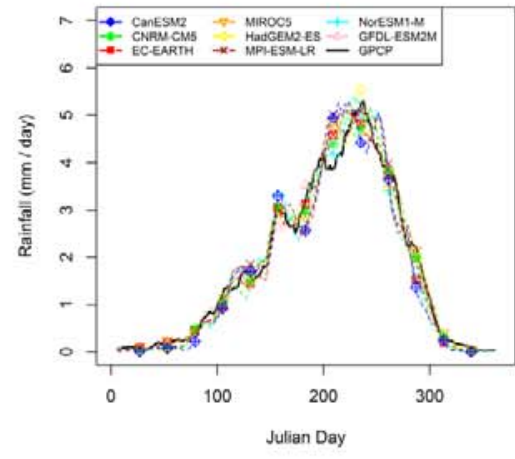

$f$

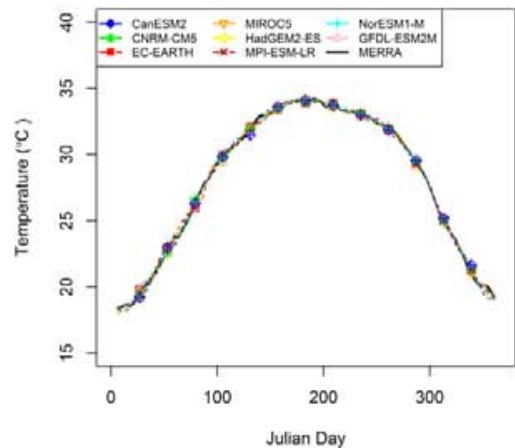

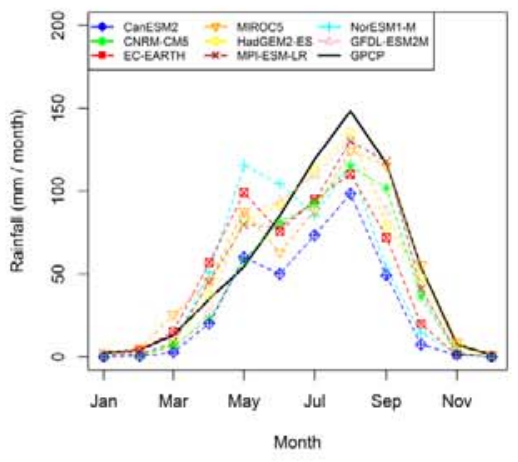

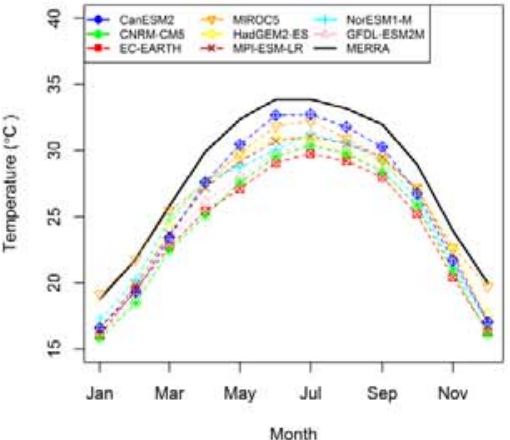

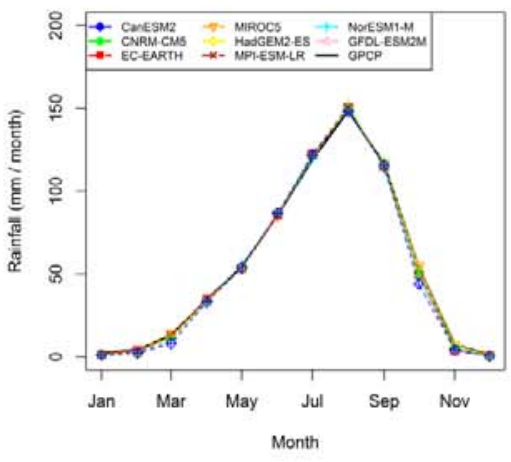

h

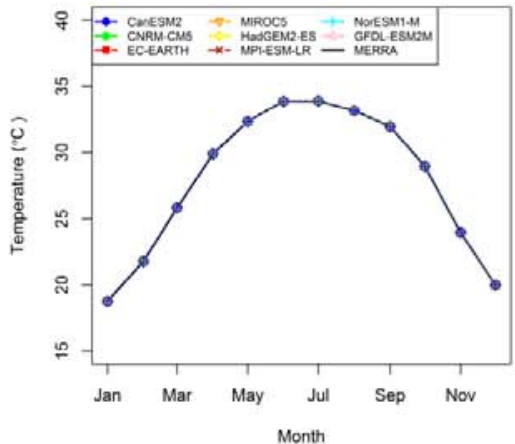

Figure 3. Comparison of CMIP5 rainfall and temperature simulations with GPCP and MERRA before and after bias correction for the evaluation period (1997-2010). (a) Climatological (daily mean from 1997-2010) rainfall before bias correction; (b) climatological rainfall after bias correction; (c) monthly mean rainfall before bias correction; (d) monthly mean rainfall after bias correction; (e) climatological temperature before bias correction; (f) climatological temperature after bias correction; (g) monthly mean temperature before bias correction; (h) monthly mean temperature after bias correction. 


\subsection{Hydroclimatic Projections}

Annual and monthly projected rainfall, temperature, PET and runoff ensemble mean from 8 GCMs are displayed in Figures 4 and 5 respectively.

\subsection{Rainfall}

Annual rainfall will go through a highly significant $(p<0.01)$ regime shift at 2050 with about $80 \mathrm{~mm}$ (RCP8.5) increase relative to the historical average (Figure 4a). Under RCP4.5, about $40 \mathrm{~mm}$ highly significant $(p<0.01)$ upward shift at 2019 will be experienced. Monthly near and far future rainfall trends are presented in Figure 5. Higher changes were observed for August and September under the two scenarios for both terms. Under RCP4.5 scenario, the near future (Figure 5a) will be ascribed with significant $(p<0.05)$ rainfall decrease at January and March. Significant increase $(p<0.05)$ will be witnessed at July while August and September will experience a highly significant increase $(p<0.01)$. At the far future (Figure $5 b)$, highly significant decrease $(p<0.01)$ in rainfall will be prominent at January while highly significant increases $(p<0.01)$ will be witnessed at July, August and September. RCP8.5 near future (Figure 5a) will be characterized by no significant decrease in rainfall, highly significant $(p<0.01)$ increases will be witnessed at September while significant increase $(p<0.05)$ will be prominent in June, July and August. At the far future (Figure $5 b$ ), RCP 8.5 will be characterized by highly significant $(p<0.01)$ decrease in rainfall at January and December (significant at $p<0.05$ ) while highly significant increases will be witnessed at July, August and September and significant increases $(p<0.05)$ are expected at May, June and October.

a

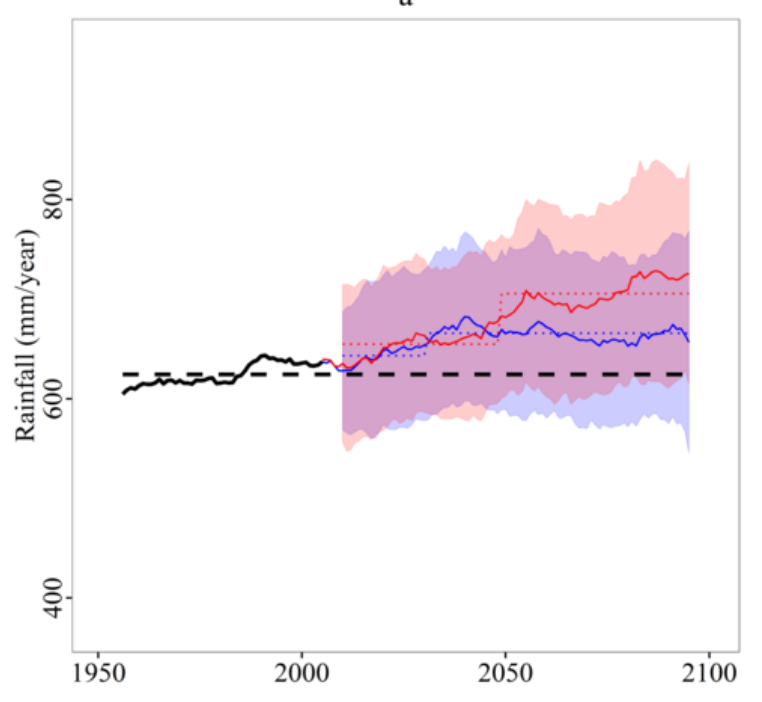

b

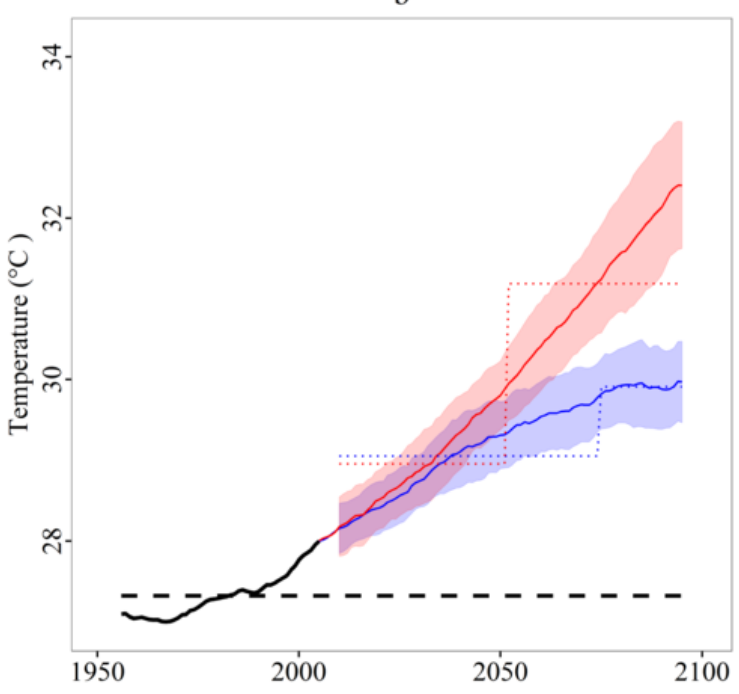

Figure 4. Cont. 
$\mathrm{c}$

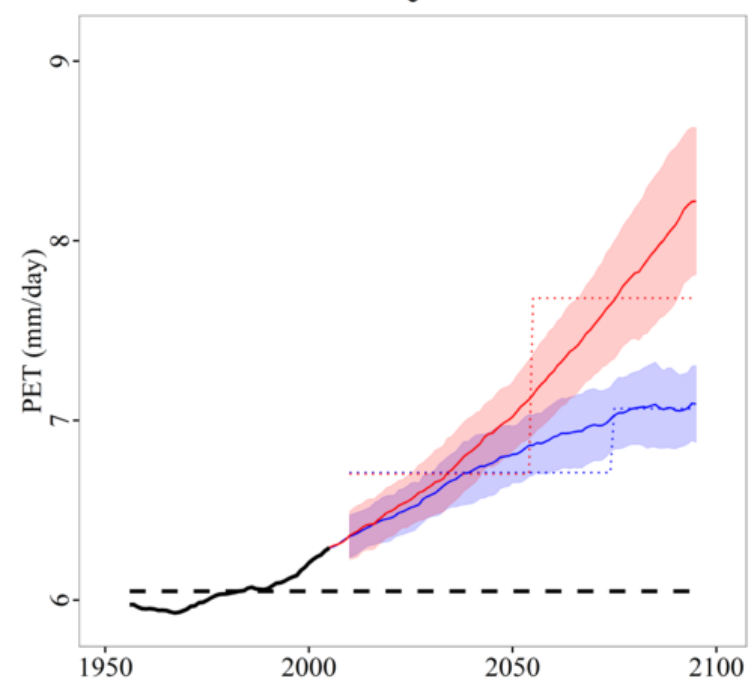

d

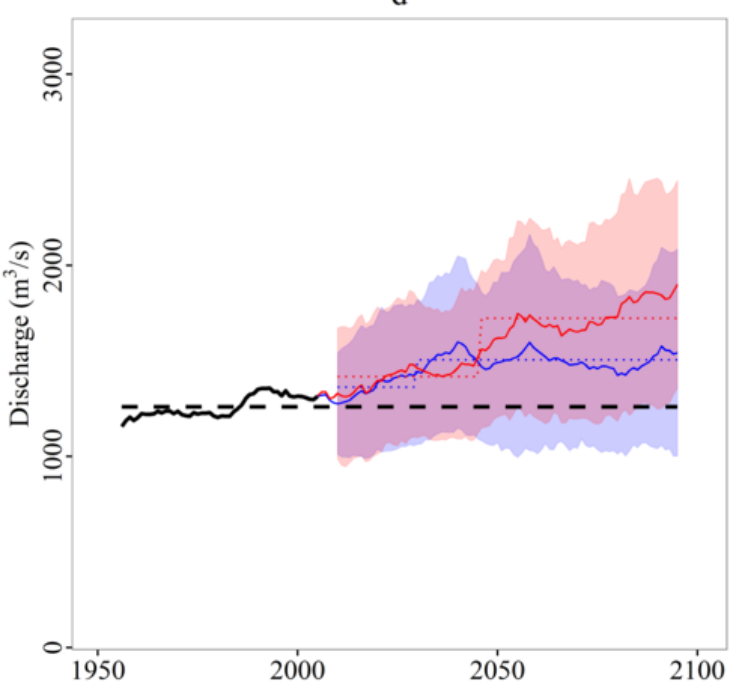

Figure 4. Projected annual climate and discharge trends from eight GCMs in the Niger Basin. (a) Rainfall; (b) temperature; (c) PET; (d) discharge: thick black line represents ensemble mean historical trend (1961-2005), red lines represent ensemble mean RCP8.5, blue lines represent ensemble mean RCP4.5; standard deviations across the GCMs are shown in surrounding bounds. Dotted lines show significant $(p<0.01)$ regime shifts and dashed black lines is the historical mean.

\subsection{Temperature}

With respect to the historical mean, at mid-century, annual mean temperature will go through a highly significant $(p<0.01) 3.5^{\circ} \mathrm{C}$ upward regime shift under RCP8.5 compared with about $2{ }^{\circ} \mathrm{C}$ rise $(p<0.01)$ under RCP4.5 (Figure 4b). Monthly near and far future temperature trends are presented in Figure $5 \mathrm{c}$,d. About $1-2{ }^{\circ} \mathrm{C}$ increase highly significant at $p<0.01$ in temperature is computed across the months in the near future (Figure 5c) under RCP4.5 and RCP8.5 scenarios. At the far future (Figure 5d), RCP4.5 scenario will experience about $2-3{ }^{\circ} \mathrm{C}$ highly significant increase at $p<0.01$ across the months while the RCP8.5 will witness a highly significant $(p<0.01)$ monthly temperature rise of about $3-4{ }^{\circ} \mathrm{C}$.

\subsection{PET}

In the RCP8.5 scenario, there will be a significant increase of more than $1.5 \mathrm{~mm} / \mathrm{d}(p<0.01)$ in PET with respect to historical data while under RCP4.5, the increase $(p<0.01)$ will be about $1 \mathrm{~mm} /$ day at mid-century (Figure 4c). Monthly PET will experience about $0.2-0.7 \mathrm{~mm} /$ day $(p<0.01)$ increase all through the months in the near future (Figure 5e) under both scenarios. At the far future (Figure 5f), RCP4.5 PET will increase by about $0.5-1.0 \mathrm{~mm} /$ day $(p<0.01)$ while under RCP8.5 PET, about $0.5-2.0 \mathrm{~mm} /$ day $(p<0.01)$ increase is expected. 

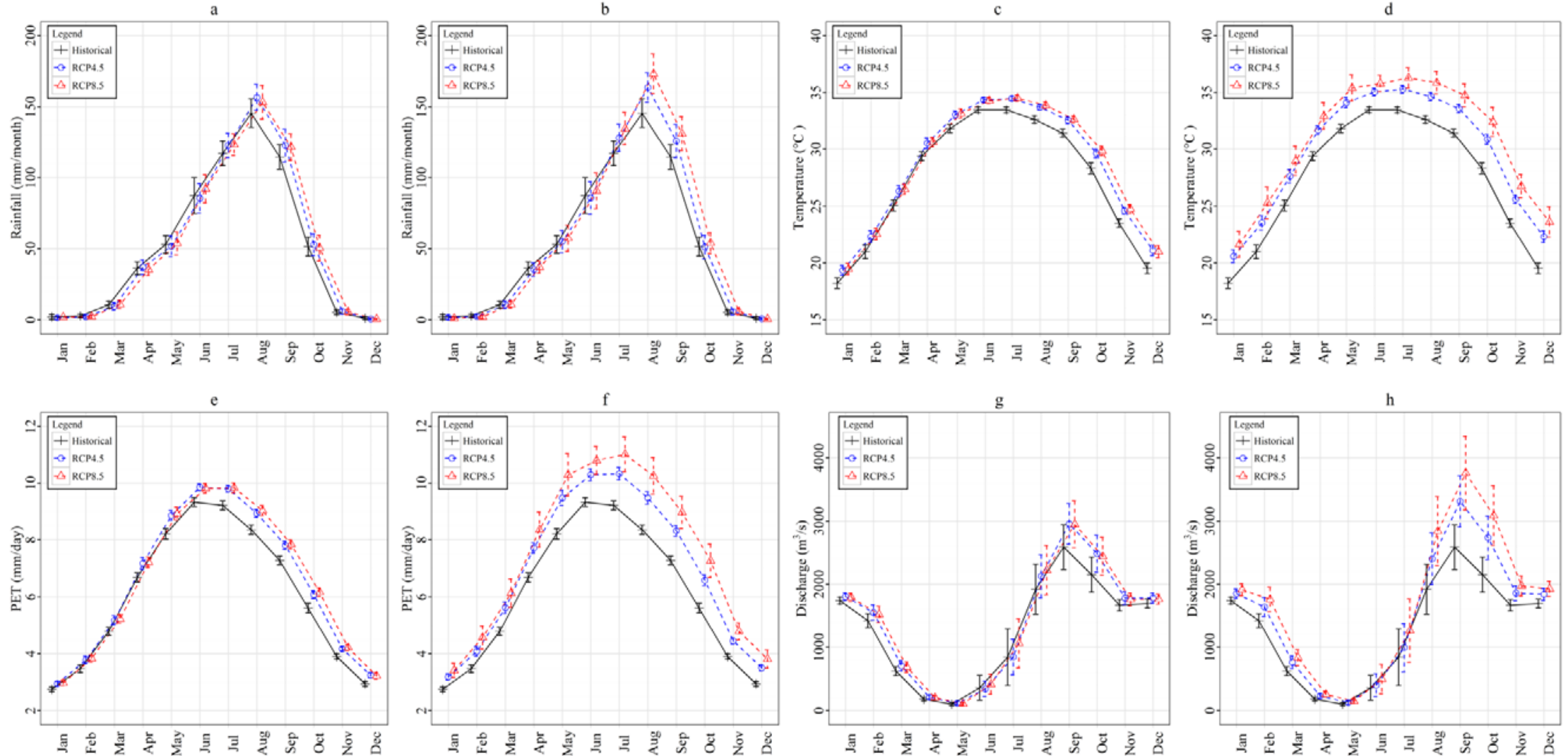

Figure 5. Ensemble mean projected monthly hydro-climatic projections from eight GCMs in the near (2010-2035) and far (2036-2099) future. (a) Near future rainfall; (b) far future rainfall; (c) near future temperature; (d) far future temperature; (e) near future PET; (f) far future PET; (g) near future discharge; (h) far future discharge: points indicates the within month means while error bars gives the within month standard deviations of the ensemble mean. 


\subsection{Discharge}

In the RCP8.5 scenario, there will be an upward ( $+400 \mathrm{~m}^{3} / \mathrm{s}$ relative to historical period) highly significant $(p<0.01)$ shift in the annual mean discharge at mid-century while about $200 \mathrm{~m}^{3} / \mathrm{s}$ increase $(p<0.01)$ will be attributed to RCP4.5 at 2031 (Figure 4d). Monthly near future showcased increases of varying magnitude throughout the months for both scenarios and time slices (Figure 5). Under RCP4.5 scenario, monthly highly significant $(p<0.01)$ increases relative to historical mean are projected at the near future (Figure 5g) at January, February, March, April, September, October, November and December while significant increases at $p<0.05$ will be attributed with May and August. At the far future (Figure $5 \mathrm{~h}$ ), highly significant $(p<0.01)$ increase in runoff will be observed in January, February, March, April, May, August, September, October, November and December. RCP8.5 near future (Figure $5 \mathrm{~g}$ ) increases $(p<0.01)$ are projected in the months of January, February, March, April, September, October, November and December while increases at July and August will be significant at $p<0.05$. At the far future (Figure $5 \mathrm{f})$ all the months will be attributed with significant $(p<0.01)$ runoff increases. In the Near Future (Table 4), all models and the ensemble predict increases in the two scenarios except EC-EARTH and MPI-ESM-LR (RCP 45) where decreases in runoff are expected. Far Future runoff will experience increases with agreements of all models and ensemble under both scenario.

\subsection{Water Balance}

From Figure 6 showing the historical data, rainfall rises gradually from March to its peak in August after which it gradually recedes to October. PET follows a gradual advancement to peak at June-July while river discharge attains its maximum annual discharge at September. Under RCP4.5, there will be increases in both near and far future rainfall (Figure 6a,c) and discharge from July to October while increase in PET will be witnessed from January to December. RCP8.5 (Figure 6b,d) revealed similar trend of increasing PET with greater magnitude compared to RCP4.5, while rainfall increases will be experienced from May to October. This increase in rainfall will trigger runoff increases from June to November (RCP45) and May to December RCP85.

Table 4. Percentage discharge trends at the near future (NF, 2010-2035) and far future (FF, 2036-2100) relative to the historical (1961-2000).

\begin{tabular}{ccccc}
\hline \multirow{2}{*}{ MODELS } & \multicolumn{4}{c}{ Discharge (\%) } \\
\cline { 2 - 5 } & RCP 45 & RCP 85 & RCP 45 & RCP 85 \\
\cline { 2 - 5 } & 13.53 & 11.28 & 23.85 & 41.50 \\
CanESM2 & 2.31 & 4.66 & 12.91 & 37.20 \\
CNRM-CM5 & -1.91 & -4.79 & 6.20 & 15.37 \\
EC-EARTH & 29.31 & 24.68 & 43.88 & 81.99 \\
MIROC5 & 11.63 & 19.74 & 15.13 & 28.68 \\
HadGEM2-ES & -0.93 & 10.46 & 0.09 & 11.65 \\
MPI-ESM-LR & 12.88 & 18.18 & 22.82 & 38.91 \\
NorESM1-M & 6.73 & 16.27 & 24.90 & 31.34 \\
GFDL-ESM2M & 8.78 & 11.95 & 18.45 & 34.91 \\
Ensemble mean & & & & \\
\hline
\end{tabular}



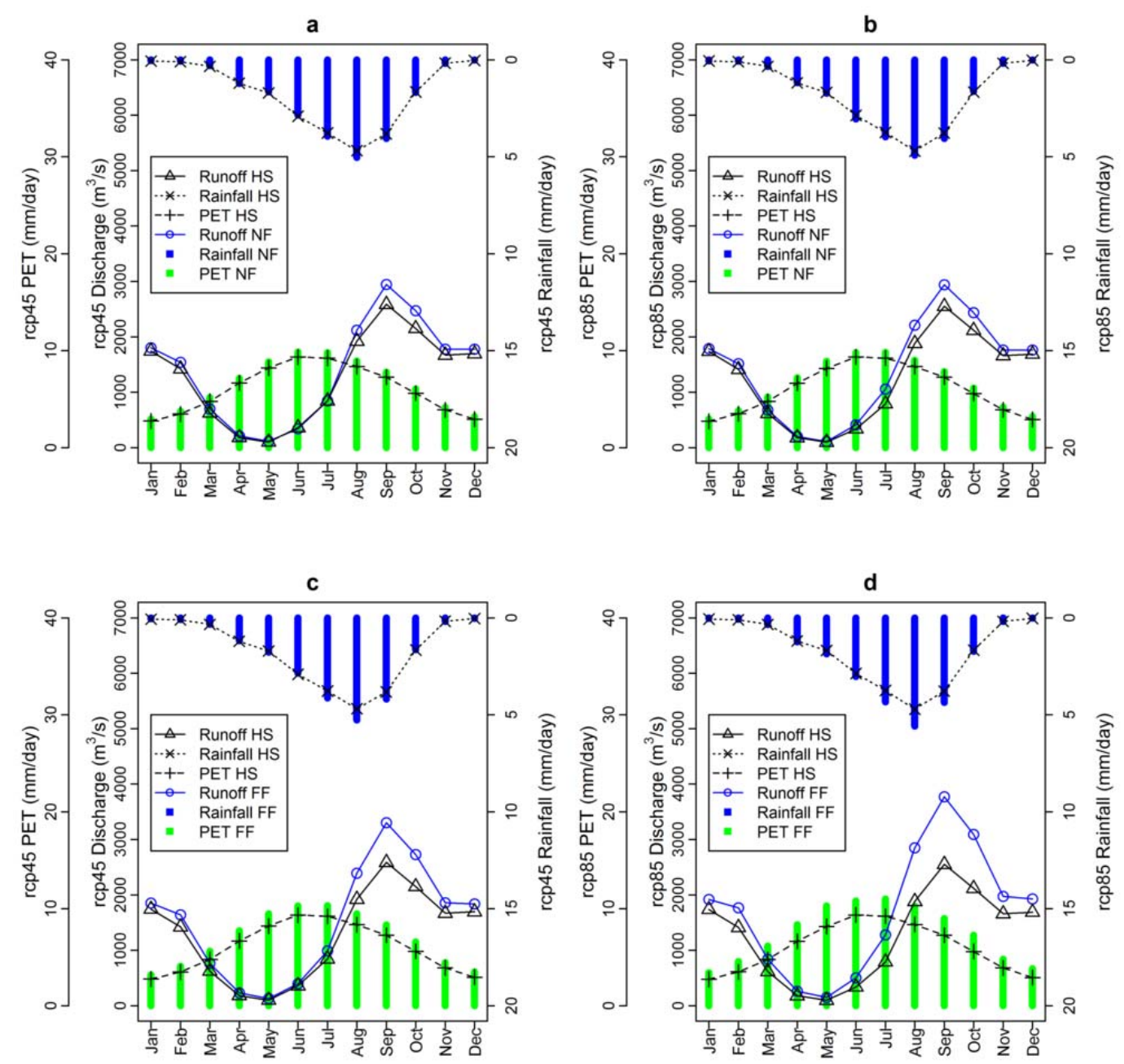

Figure 6. Monthly ensemble (8 GCMs) mean discharge response to changes in climate variables for (a) near future (NF; 2010-2035) RCP4.5 (b) near future RCP8.5 (c) far future (FF; 2036-2099) RCP4.5 and

(d) far future RCP8.5; compared with historical (HS; 1961-2005).

\section{Discussion}

The reduction of deviations among the 8 evaluated GCMs (Figure 2) by quantile mapping indicated the appropriateness of the method for the Niger basin. It was able to improve the correlations between observed and simulated rainfall and temperature. Most climate models, for example, tend to overestimate the amount of "drizzle" [55,56] and consequently generate biased data compared to observations [57]. CMIP5 models have also been attributed with such biases in West Africa $[18,22]$. The improvement of simulations with bias correction applied to the catchment suggests the appropriateness of the method. The improved hydrological model implemented here is a lumped parameter, conceptual rainfall-runoff model [29,32]. Hydrological model efficiency was evaluated by comparing simulated and observed runoff. Downscaled re-analysis was earlier shown to cause ineffective modeling for hydrological models [40]. Results here indicate that the adapted model appropriately simulates river discharge using re-analysis data and therefore gives possibility for its application to ungauged and poorly gauged basin.

The simulations predict an increase in rainfall in Sahelian parts of the Niger basin in agreement with previous studies in future. Biasutti [22] showed that the majority of the CMIP5 models project a wetter Sahel in the 21st century. Sylla et al. [16] also reported a more pronounced increase of the intensity of very wet rainfall events in the Sahel towards the end of the century. Decrease in rainfall 
in the months at the beginning of the rainy season will hamper water availability in these difficult periods. Apata et al. [58] showed that an increase of the length of the dry season have aggravated the challenges of drying-out of streams and small rivers that usually flows year round. It has also led to the seasonal shifting of pre-monsoon rainfall that are important for flowering and fruiting of mango [58]. These climate change issues will persist and aggravate as indicated in both scenarios. Projected high increases in rainfall in the wet months will lead to concurrent increases in discharge especially in the two flooding seasons (white flood and black flood). Similar patterns of discharge increase in the Niger basin due to rainfall increase was reported by Roudier et al. [2]. This will aggravate the current problematic flooding in the region $[26,59]$ which was already attributed to increasing rainfall trends and reduced infiltration due to replacement of natural (permeable) surfaces by man-made (impermeable) surfaces [8].

\section{Conclusions}

This paper showcased that the recent CMIP5 archive and concurrent bias improvements have a great potential for reducing uncertainties in hydroclimatic projections. The bias corrected CMIP5 projected rainfall-runoff patterns presented in this study showed higher confidence than previous simulations in the Niger basin; and appears to be an important tool for hydroclimatic predictions. The persisting and aggravating hydroclimatic trends disclosed under the two scenarios suggest investing more efforts towards the development of adaptation techniques, particularly in the water supply, conservation, agriculture and energy sectors. Further research will consider applying this modeling framework to various basin scales and evaluate impacts of climate change on water-related sectors, particularly water supply, agriculture and energy, which are important economic sectors in the basin, for improved adaptation strategies.

Acknowledgments: This study was funded by the German Ministry of Education and Research (BMBF) through the Center for Development Research and WASCAL-GRP CC\&WR at the University of Abomey Calavi. ESGF grid (http:/ / esg-dn1.nsc.liu.se/esgf-web-fe/) which provides CORDEX-Africa data is appreciated. The Niger Basin Authority is appreciated for providing the river discharge data.

Author Contributions: All figures and tables were done by Ganiyu Titilope Oyerinde, Fabien C.C. Hountondji and Bernd Diekkrüger. Manuscript writing was made by Ganiyu Titilope Oyerinde, Fabien C.C. Hountondji and Bernd Diekkrüger. The Ph.D. Thesis where the manuscript was derived from was supervised and examined by Fabien C.C. Hountondji, Ayo J. Odofin, Abel Afouda and Agnide E. Lawin.

Conflicts of Interest: The authors declare no conflict of interest.

\section{References}

1. IPCC Summary for Policymakers. Climate Change 2014: Impacts, Adaptation, and Vulnerability. Part A: Global and Sectoral Aspects. Contribution of Working Group II to the Fifth Assessment Report of the Intergovernmental Panel on Climate Change; Field, C.B., Barros, V.R., Dokken, D.J., Mach, K.J., Mastrandrea, M.D., Bilir, T.E., Chatterjee, M., Ebi, K.L., Estrada, Y.O., Genova, R.C., et al., Eds.; Cambridge University Press: Cambridge, UK; New York, NY, USA, 2014; pp. 1-32.

2. Roudier, P.; Ducharne, A.; Feyen, L. Climate change impacts on river discharge in West Africa: A review. Hydrol. Earth Syst. Sci. Discuss. 2014, 11, 2483-2514. [CrossRef]

3. Lebel, T.; Ali, A. Recent trends in the Central and Western Sahel rainfall regime (1990-2007). J. Hydrol. 2009, 375, 52-64. [CrossRef]

4. Amogu, O.; Descroix, L.; Yéro, K.S.; Le Breton, E.; Mamadou, I.; Ali, A.; Vischel, T.; Bader, J.-C.; Moussa, I.B.; Gautier, E.; et al. Increasing River Flows in the Sahel? Water 2010, 2, 170-199. [CrossRef]

5. Novotny, E.V.; Stefan, H.G. Stream flow in Minnesota: Indicator of climate change. J. Hydrol. 2007, 334, 319-333. [CrossRef]

6. Lebel, T.; Diedhiou, A.; Henri, L. Seasonal cycle and interannual variability of the Sahelian rainfall at hydrological scales. J. Geophys. Res. 2003, 108, 1-11. [CrossRef] 
7. Laprise, R.; Hernández-Díaz, L.; Tete, K.; Sushama, L.; Šeparović, L.; Martynov, A.; Winger, K.; Valin, M. Climate projections over CORDEX Africa domain using the fifth-generation Canadian Regional Climate Model (CRCM5). Clim. Dyn. 2013, 41, 3219-3246. [CrossRef]

8. Chineke, T.; Idinoba, M. Seasonal evapotranspiration signatures under a changing landscape and ecosystem management in Nigeria: Implications for agriculture and food security. Am. J. Sci. Ind. Res. 2011, 2, 191-204. [CrossRef]

9. Druyan, L.M. Studies of 21st-century precipitation trends over West Africa. Int. J. Climatol. 2011, 31, 1415-1424. [CrossRef]

10. Vetter, T.; Huang, S.; Aich, V.; Yang, T.; Wang, X.; Krysanova, V.; Hattermann, F. Multi-model climate impact assessment and intercomparison for three large-scale river. Earth Syst. Dyn. 2015, 6, 17-43. [CrossRef]

11. Diallo, I.; Sylla, M.B.; Giorgi, F.; Gaye, A.T.; Camara, M. Multimodel GCM-RCM Ensemble-Based Projections of Temperature and Precipitation over West Africa for the Early 21st Century. Int. J. Geophys. 2012, 2012, 1-19. [CrossRef]

12. Mertz, O.; D’haen, S.; Maiga, A.; Moussa, I.B.; Barbier, B.; Diouf, A.; Diallo, D.; Da, E.D.; Dabi, D. Climate variability and environmental stress in the Sudan-Sahel zone of West Africa. Ambio 2012, 41, 380-392. [CrossRef] [PubMed]

13. Mariotti, L.; Coppola, E.; Sylla, M.B.; Giorgi, F.; Piani, C. Regional climate model simulation of projected 21st century climate change over an all-Africa domain: Comparison analysis of nested and driving model results. J. Geophys. Res. 2011, 116, D15111. [CrossRef]

14. Oguntunde, P.G.; Abiodun, B.J. The impact of climate change on the Niger River Basin hydroclimatology, West Africa. Clim. Dyn. 2013, 40, 81-94. [CrossRef]

15. Panitz, H.-J.; Dosio, A.; Büchner, M.; Lüthi, D.; Keuler, K. COSMO-CLM (CCLM) climate simulations over CORDEX-Africa domain: Analysis of the ERA-Interim driven simulations at $0.44^{\circ}$ and $0.22^{\circ}$ resolution. Clim. Dyn. 2013, 42, 3015-3038. [CrossRef]

16. Sylla, M.B.; Giorgi, F.; Pal, J.S.; Gibba, P.; Kebe, I.; Nikiema, M. Projected Changes in the Annual Cycle of High Intensity Precipitation Events over West Africa for the Late 21st Century. J. Clim. 2015, [CrossRef]

17. Sylla, M.B.; Gaye, A.T.; Jenkins, G.S.; Pal, J.S.; Giorgi, F. Consistency of projected drought over the Sahel with changes in the monsoon circulation and extremes in a regional climate model projections. J. Geophys. Res. 2010, 115, D16108. [CrossRef]

18. Klutse, N.A.B.; Sylla, M.B.; Diallo, I.; Sarr, A.; Dosio, A.; Diedhiou, A.; Kamga, A.; Lamptey, B.; Ali, A.; Gbobaniyi, E.O.; et al. Daily characteristics of West African summer monsoon precipitation in CORDEX simulations. Theor. Appl. Climatol. 2015, 1-17. [CrossRef]

19. Oyerinde, G.T.; Wisser, D.; Hountondji, F.C.C.; Odofin, A.J.; Lawin, A.E.; Afouda, A.; Diekkrüger, B. Quantifying Uncertainties in Modeling Climate Change Impacts on Hydropower Production. Climate 2016, 4, 1-15. [CrossRef]

20. KfW Adaptation to Climate Change in the Upper and Middle Niger River Basin. Available online: http: / /ccsl.iccip.net/niger_river_basin.pdf (accessed on 12 February 2017).

21. Ghile, Y.B.; Taner, M.Ü.; Brown, C.; Grijsen, J.G. Bottom-up climate risk assessment of infrastructure investment in the Niger River Basin. Clim. Chang. 2014, 122, 97-110. [CrossRef]

22. Biasutti, M. Forced Sahel rainfall trends in the CMIP5 archive. J. Geophys. Res. Atmos. 2013, 118, $1613-1623$. [CrossRef]

23. Gbobaniyi, E.; Sarr, A.; Sylla, M.B.; Diallo, I.; Lennard, C.; Dosio, A.; Dhiédiou, A.; Kamga, A.; Klutse, N.A.B.; Hewitson, B.; et al. Climatology, annual cycle and interannual variability of precipitation and temperature in CORDEX simulations over West Africa. Int. J. Climatol. 2014, 34, 2241-2257. [CrossRef]

24. Gudmundsson, L.; Bremnes, J.B.; Haugen, J.E.; Engen-Skaugen, T. Technical Note: Downscaling RCM precipitation to the station scale using statistical transformations-A comparison of methods. Hydrol. Earth Syst. Sci. 2012, 16, 3383-3390. [CrossRef]

25. Ogilvie, A.; Mahéé, G.; Ward, J.; Serpantiéé, G.; Lemoalle, J.; Morand, P.; Barbier, B.; Kaczan, D.; Lukasiewicz, A.; Paturel, J.; et al. Water, agriculture and poverty in the Niger River basin. Water Int. 2010, 35, 594-622. [CrossRef]

26. Oyerinde, G.T.; Hountondji, F.C.C.; Wisser, D.; Diekkrüger, B.; Lawin, A.E.; Odofin, A.J.; Afouda, A. Hydro-climatic changes in the Niger basin and consistency of local perceptions. Reg. Environ. Chang. 2015, 15, 1627-1637. [CrossRef] 
27. Andrews, F.T.; Croke, B.F.W.; Jakeman, A.J. An open software environment for hydrological model assessment and development. Environ. Model. Softw. 2011, 26, 1171-1185. [CrossRef]

28. R Development Core Team R: A Language and Environment for Statistical Computing. Available online: http:/ / www.r-project.org (accessed on 13 August 2015).

29. Ye, W.; Bates, B.C.; Viney, N.R.; Sivapalan, M. Performance of conceptual rainfall-runoff models in low-yielding ephemeral catchments. Water Resour. Res. 1997, 33, 153-166. [CrossRef]

30. Croke, B.; Jakeman, A. Use of the IHACRES rainfall-runoff model in arid and semi arid regions. In Hydrological Modelling in Arid and Semi-Arid Areas; Wheater, H., Sorooshian, S., Sharma, K.D., Eds.; Cambridge University Press: Cambridge, UK, 2008; pp. 41-48.

31. Andrews, F. ARMAX Transfer Function Models. Available online: http://hydromad.catchment.org/man/ armax.html (accessed on 30 March 2016).

32. Jakeman, A.J.; Littlewood, I.G.; Whitehead, P.G. Computation of the instantaneous unit hydrograph and identifiable component flows with application to two small upland catchments. J. Hydrol. 1990, 117, 275-300. [CrossRef]

33. Dutta, D.; Welsh, W.; Vaze, J.; Kim, S.; Nicholls, D. Improvement in short-term streamflow forecasting using an integrated modelling framework. In Proceedings of the 19th International Congress on Modelling and Simulation, Perth, Australia, 12-16 December 2011.

34. Jakeman, A.; Hornberger, G. How much complexity is warranted in a rainfall-runoff model? Water Resour. Res. 1993, 29, 2637-2649. [CrossRef]

35. Andrews, F. IHACRES Catchment Wetness Index (CWI) Model. Available online: http://hydromad. catchment.org/man/IHACRES.CWI.model.html (accessed on 31 May 2016).

36. Huffman, G.J.; Adler, R.F.; Arkin, P.; Chang, A.; Ferraro, R.; Gruber, A.; Janowiak, J.; Mcnab, A.; Rudolf, B.; Schneider, U. The Global Precipitation Climatology Project (GPCP) Combined Precipitation Dataset. Bull. Am. Meteorol. Soc. 1997, 78, 5-20. [CrossRef]

37. Rienecker, M.M.; Suarez, M.J.; Gelaro, R.; Todling, R.; Bacmeister, J.; Liu, E.; Bosilovich, M.G.; Schubert, S.D.; Takacs, L.; Kim, G.K.; et al. MERRA: NASA's modern-era retrospective analysis for research and applications. J. Clim. 2011, 24, 3624-3648. [CrossRef]

38. Ali, A.; Lebel, T. The Sahelian standardized rainfall index revisited. Int. J. Climatol. 2009, 29, 1705-1714. [CrossRef]

39. Jobard, I.; Chopin, F.; Berges, J.C.; Roca, R. An intercomparison of 10-day satellite precipitation products during West African monsoon. Int. J. Remote Sens. 2011, 32, 2353-2376. [CrossRef]

40. Gosset, M.; Viarre, J. Evaluation of several rainfall products used for hydrological applications over West Africa using two high-resolution gauge networks. Q. J. R. Meteorol. Soc. 2013, 139, 923-940. [CrossRef]

41. Lehner, B.; Verdin, K.; Jarvis, A. New global hydrography derived from spaceborne elevation data. EOS Trans. Am. Geophys. Union 2008, 89, 93-94. [CrossRef]

42. Jasiewicz, J.; Metz, M. A new GRASS GIS toolkit for Hortonian analysis of drainage networks. Comput. Geosci. 2011, 37, 1162-1173. [CrossRef]

43. Lucio, P.; Molion, L.; Valadão, C.; Conde, F.; Ramos, A.; de Melo, M.L.D. Dynamical outlines of the rainfall variability and the ITCZ role over the West Sahel. Atmos. Clim. Sci. 2012, 2, 337-350. [CrossRef]

44. Oudin, L.; Hervieu, F.; Michel, C.; Perrin, C.; Andréassian, V.; Anctil, F.; Loumagne, C. Which potential evapotranspiration input for a lumped rainfall-runoff model? J. Hydrol. 2005, 303, 290-306. [CrossRef]

45. Giorgi, F.; Jones, C.; Asrar, G.R. Addressing climate information needs at the regional level: The CORDEX framework. WMO Bull. 2009, 58, 175-183.

46. Taylor, K.E.; Stouffer, R.J.; Meehl, G.A. An Overview of CMIP5 and the Experiment Design. Bull. Am. Meteorol. Soc. 2012, 93, 485-498. [CrossRef]

47. Su, F.; Duan, X.; Chen, D.; Hao, Z.; Cuo, L. Evaluation of the Global Climate Models in the CMIP5 over the Tibetan Plateau. J. Clim. 2013, 26, 3187-3208. [CrossRef]

48. Killick, R. changepoint: An R Package for Changepoint Analysis. J. Stat. Softw. 2014, 58, 1-19. [CrossRef]

49. Kling, H.; Fuchs, M.; Paulin, M. Runoff conditions in the upper Danube basin under an ensemble of climate change scenarios. J. Hydrol. 2012, 424-425, 264-277. [CrossRef]

50. Ravazzani, G.; Dalla Valle, F.; Gaudard, L.; Mendlik, T.; Gobiet, A.; Mancini, M. Assessing Climate Impacts on Hydropower Production: The Case of the Toce River Basin. Climate 2016, 4, 16. [CrossRef] 
51. Sarr, M.A.; Seidou, O.; Tramblay, Y.; Adlouni, S. Journal of Hydrology: Regional Studies Comparison of downscaling methods for mean and extreme precipitation in Senegal. J. Hydrol. Reg. Stud. 2015, 4, 369-385. [CrossRef]

52. Nash, J.E.; Sutcliffe, J.V. River flow forecasting through conceptual models part I-A discussion of principles. J. Hydrol. 1970, 10, 282-290. [CrossRef]

53. Legates, D.R.; McCabe, G.J. Evaluating the use of "goodness-of-fit" measures in hydrologic and hydroclimatic model validation. Water Resour. Res. 1999, 35, 233-241. [CrossRef]

54. Shin, M.; Guillaume, J.; Croke, B.; Jakeman, A. Addressing ten questions about conceptual rainfall-runoff models with global sensitivity analyses in R. J. Hydrol. 2013, 503, 135-152. [CrossRef]

55. Perkins, S.E.; Pitman, A.J.; Holbrook, N.J.; McAneney, J. Evaluation of the AR4 climate models' simulated daily maximum temperature, minimum temperature, and precipitation over Australia using probability density functions. J. Clim. 2007, 20, 4356-4376. [CrossRef]

56. Sun, Y.; Solomon, S.; Dai, A.; Portmann, R.W. How often does it rain? J. Clim. 2006, 19, 916-934. [CrossRef]

57. Lenderink, G.; Buishand, A.; van Deursen, W. Estimates of future discharges of the river Rhine using two scenario methodologies: Direct versus delta approach. Hydrol. Earth Syst. Sci. 2007, 11, 1145-1159. [CrossRef]

58. Apata, T.; Samuel, K.; Adeola, A. Analysis of Climate Change Perception and Adaptation among Arable Food Crop Farmers in South Western Nigeria. Available online: https:/ / pdfs.semanticscholar.org/abeb/ 4f07b37bf7177dae41387b69541b4800320e.pdf (accessed on 12 February 2017).

59. Tschakert, P.; Sagoe, R.; Samuel, G.O.; Codjoe, N. Floods in the Sahel: An analysis of anomalies, memory, and anticipatory learning. Clim. Chang. 2010, 103, 471-502. [CrossRef]

(C) 2017 by the authors; licensee MDPI, Basel, Switzerland. This article is an open access article distributed under the terms and conditions of the Creative Commons Attribution (CC BY) license (http:/ / creativecommons.org/licenses/by/4.0/). 